\title{
圧縮を受ける円形鋼管短柱の塑性流れ域での安定性に関する研究 \\ - 象の足座屈に扮ける理論と実験事実の乘離 - \\ A STUDY ON THE STABILITY OF CIRCULAR SECTION STEEL STUB-COLUMNS \\ IN THE PLASTIC-FLOW REGION
}

- Discrepancy between theory and experimental result for elephant-foot buckling -

井上哲郎*，竹端陽一**

Tetsuro INOUE and Yoichi TAKEHANA

\begin{abstract}
Maximum stress obtained by compression test of circular steel stub-columns were compared with deformation theory and incremental stress-strain theory. Each buckling analysis has a term of tangent modulus $\mathrm{E}_{\mathrm{t}}$ in its solution. Therefore these solutions are commonly considered that all specimens lose stability in the plastic-flow region. This paper shows that specimens with small diameter-to-thickness ratio can be compressed beyond plastic flow region by reconsidering past plastic theories.
\end{abstract}

Keywords : Circular section steel stub-column, plastic-flow region, elephant-foot buckling,

compression test、 tangent modulus theory

円形鋼管短柱, 塑性流れ域, 象の足座屈, 圧縮実験、接線係数理論

\section{1.はじめに}

圧縮を受ける円形鋼管短柱の塑性域における軸対称モードの座屈 耐力について接線係数理論の立場から、特に塑性流れ域での安定性 について考察する。塑性域での座屈問題を過去に扱った理論として 変形理論と歪増分理論がある。しかしよく知られている変形理論解、 歪増分理論解共に接線係数 $E_{t}$ の項がかかっており、歪硬化域に達す る前に塑性流れ域を経験するので、どんなに径厚比が小さくても固 有值的には塑性流れ域に至ると $E_{t}=0$ となってここで座屈してし まう。それにもかかわらず円形鋼管は径厚比が小さくなると、塑性 流れ域に至るとただちに座屈せずに歪硬化域に達するような振る舞 いを示すのは実験事実の示すところであり、理論との間に乘離が存 在すると言わざるを得ない。そこで本研究では歪増分理論では塑性 流れ域で、応力増分と歪増分との関係を非硬化材料に対する Reuss 方程式を適用寸る事から出発して表し、これが硬化材料の場合の一 般式において $E_{t} \rightarrow 0$ の極限と一致することを確認した。この間の説 明は (APPENDIX I ) に示される。この一般式を用いて行った座屈 解析の結果は既に他の研究者により明らかにされている。そこで得 られている座屈耐力式は塑性流れ域においては $E_{t}$ に 0 を代入する と発散する項が含まれているのでそのままでは使えない。しかし
$E_{t} \rightarrow 0$ の極限をとれば極限值が存在し、それは筆者が上述の Reuss の方程式からひも解いて求めた解と一致するのでこの一般式 をそのまま引用し、これを元に議論を進めることとした。解析の結 果上述の乘離を埋める新しい知見を得た。それは塑性流れ域では軸 対称座屈耐力解は座屈半波長に反比例する形となり、塑性流れ域に 至って耐力を全く失うのは無限に長い柱の場合である。又実験で観 察される象の足モードのように短い半波長で座屈する軸対称座屈の 場合は、例え歪の戻りの無い条件下でも、径厚比によっては塑性流 れ域で安定を失うことなく歪硬化域に達し得ることである。この知 見は変形理論解についても同様である。

上記の理論は、降伏比と塑性流れ域の長さが異なる 3 種類のシリ ーズの熱間成形鋼管短柱の圧縮実験を行って検証した。

\section{2. 歪増分理論、変形理論から導かれた理論座屈式}

\section{1 歪硬化域}

釣り合い式としてDonnel ${ }^{1)}$ が円管の站じり座屈問題に対して提案 した比較的簡素な式に基づき、この式を圧縮を受ける円管の、軸対 称モード座屈の問題に適用し、変形理論に基づく解の一般形として 下式が導かれている。この式はパラメータの值を適切に選ぶことに

\footnotetext{
* 筑波大学システム情報工学研究科 教授・工博

** 富山市役所 工修
}

Prof., Dept. of Engineering Mechanics and Energy, Graduate School of Systems and Information Engineering, University of Tsukuba, Dr. Eng.

Toyama City Office, M. Eng. 
より、弾性座屈理論解および歪増分理論に基づく座屈理論解をも含 む統一的表現である ${ }^{2)}$

$$
\begin{gathered}
\sigma_{c r}=\frac{2 E}{\sqrt{\left.\left.3(3 \psi+2-4 v) \lambda-(1-2 v)^{2}\right)\right\}}} \times \frac{t}{R} \\
L=\frac{\pi \sqrt{t \times R(\lambda+3 \psi)}}{2 \times \sqrt[4]{\left.3(3 \psi+2-4 v) \lambda-(1-2 v)^{2}\right\}}}
\end{gathered}
$$

ここに

$$
\begin{aligned}
& \sigma_{c r}: \text { 座屈応力度 } \\
& \lambda=E / E_{t} \\
& \psi=E / E s \\
& t: \text { 管厚 } \\
& v: \text { ポアソン比 } \\
& R: \text { 平均半径 } \\
& L: \text { 座屈半波長 } \\
& E: \text { ヤング率 } \\
& E_{t}: \text { 接線係数 } \\
& E_{S}: \text { 割線係数 }
\end{aligned}
$$

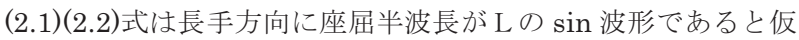
定して、微分方程式を解く過程で得られる下式を最小にする条件か ら得たものである。この時円管の軸方向の長さ（材長）が無限大で あれば、。は $\pi / \mathrm{L} の$ 連続関数と考えてよい。

$$
\sigma_{c r}=\frac{I a_{11}}{t}\left(\frac{\pi}{L}\right)^{2}+\frac{B E}{R^{2} a_{11}}\left(\frac{L}{\pi}\right)^{2}
$$

ここに

$$
\begin{aligned}
& I=\frac{t^{3}}{12} \\
& a_{11}=B \times \frac{\lambda+3 \psi}{4} \\
& B=\frac{4 E}{(3 \psi+2-4 v) \lambda-(1-2 v)^{2}}
\end{aligned}
$$

こうして得た $\sigma_{c r}$ のとり得る最小值は、塑性流れ域 $\left(E_{t}=0\right)$ 以外 では(2.1)，(2.2)式が適用される。この式から各パラメータに下記に 示寸場合に応じた值を代入することにより、各理論の座屈理論解が 得られる。

(1) 弾性座屈理論解

この場合は $\lambda=\psi=1$ を代入して下式のように得られる ${ }^{2)}$

$$
\sigma_{c r}=\frac{E}{\sqrt{3\left(1-v^{2}\right)}} \cdot \frac{t}{R}
$$

（2）変形理論に基づく座屈理論解

この場合は $\psi=E / E_{S}$ とし、塑性化が十分進行した後に局部座 屈する場合、 $\lambda, \psi$ の值は $(1-2 v)$ より 1 オーダー大きい值となって おり (2.1)式に材料の非圧縮性 $(v=1 / 2)$ を付加すると次式に漸近する 2) 3) 4)

$$
\sigma_{c r}=\frac{2}{3} \sqrt{E_{S} E_{t}} \frac{t}{R}
$$

(3) 歪増分理論に基づく座屈理論解 この場合は(2.1)式に $\psi=1$ と置いて下式のように得られる ${ }^{2)} 。$

$$
\sigma_{c r}=\frac{2 E}{\sqrt{3\left((5-4 v) \lambda-(1-2 v)^{2}\right\}}} \cdot \frac{t}{R}
$$

(2.6)式で塑性域では $\lambda$ が大きく、それに対して $(1-2 v)^{2}$ が無視で きると見なすと次式を得る ${ }^{5)}$ 。

$$
\begin{aligned}
\sigma_{c r}= & \frac{1}{1.69} \sqrt{E E_{t}} \frac{t}{R} \\
& \text { 但し } V=0.3 \text { とした。 }
\end{aligned}
$$

（4）自由境界に対する、歪増分理論に基づく座屈理論解

この解はもともと弾性座屈理論解が実験結果に対して高すぎる 解しか与えないので、理論解が下がる可能性を追求して考え出し た端部の境界条件を自由境界とする仮定を、歪増分理論に基づく 座屈理論解にも適用したものである。その結果下式が提案されて いる ${ }^{6)}$ 。

$$
\sigma_{c r}=\frac{E}{\sqrt{3\left\{(5-4 v) \lambda-(1-2 v)^{2}\right\}}} \cdot \frac{t}{R}
$$

この式は次のように書き表される。

$$
\sigma_{c r}=\frac{1}{3.38} \sqrt{E E_{t}} \frac{t}{R}
$$

この解は(2.6)式の $1 / 2$ である。

\section{2 塑性流れ域}

ところで塑性流れ域では $E_{t}=0(\lambda=\infty)$ であるので、これを(2.1) 式に代入すると、 $\sigma_{c r}=0$ となってしまう。これは塑性流れ域で座 屈してしまうことを意味する。しかしこの時の座屈半波長は(2.2)式 によればゅとなり、これは短柱を扱っているのでありえない。この 場合は(2.3)式に立ち返って考察しなければならない。(2.3)式はその まま計算すると発散する項を含んでいるが $E_{t} \rightarrow 0$ の極限が存在す る。その極限が塑性流れ域の理論座屈式である。

(a) 変形理論解

(2.3)式に $E_{t}=0 \quad a_{11}=\frac{E_{S}}{3} \quad B E=0$ を代入して次式を得る。

$$
\sigma_{c r}=\frac{t^{2}}{36} E_{S}\left(\frac{\pi}{L}\right)^{2}
$$

(b)歪増分理論解

$(2.3))$ 式に $E_{t}=0 \quad \psi=1 \quad a_{11}=\frac{E}{5-4 v} \quad B E=0 \quad$ を代入して次 式を得る。

$$
\sigma_{c r}=\frac{I a_{11}}{t}\left(\frac{\pi}{L}\right)^{2}=\frac{t^{2}}{12} \times \frac{E}{5-4 v}\left(\frac{\pi}{L}\right)^{2}
$$

（2.10）、(2.11)式は両式とも座屈半波長を無限大としたときに、耐 力 0 を与えるので、塑性流れ域で不安定となることを示している。 又座屈半波長が有限であるときには耐力を持つことを、式の形は示 している。このことは、短柱の長さが有限であること、又実験で観 察される座屈波は像の足モードのように端部に集中した短い波長で あることと符合している。塑性流れ域に(2.10),(2.11)式を適用する意 味は応力度は降伏応力度ただ一つに適用するのであるから、径厚比 によって、これらの式の与える值が降伏応力度以上であれば塑性流 
れ域で安定、低いと不安定で座屈することを意味している。

\section{3. 円形鋼管端柱の圧縮実験}

\section{1 試験体}

円形鋼管短柱試験体は材質の相違の影響をみる為に降伏応力と 降伏比そして降伏棚の長さが異なる 3 種類のシリーズからなる。そ れらはSS400,配管用熱間圧延継目無鋼管 STPT410-S-Hおよび強度 の高い機械構造用炭素鋼継目無鋼管 STKM-S45C である。

試験体はすべて製作後 $600^{\circ} \mathrm{C} 15$ 分保持後、炉冷により残留応力除 去焼鈍がなされている。SS400 の試験体は材長が $150 \mathrm{~mm}$ 又は $100 \mathrm{~mm}$ の 2 種類があり、径厚比は 19 種類ある。STPT410-S-H の 試験体の径厚比は 18 種類ある。STKM-S45C の試験体の径厚比は 19 種類ある。

試験体名としては、SS400 は材長 $150 \mathrm{~mm}$ のものは CL3〜10、 100mm のものは CS8〜18、STPT410-S-H は st-1〜18、STKM$\mathrm{S} 45 \mathrm{C}$ は sc-1〜19 がある。試験体は外径を揃え内径を削ることによ つて製作した。これらの寸法等は表 1〜表 3 に示す。これらの図、 表中の記号の意味は図中に示す。
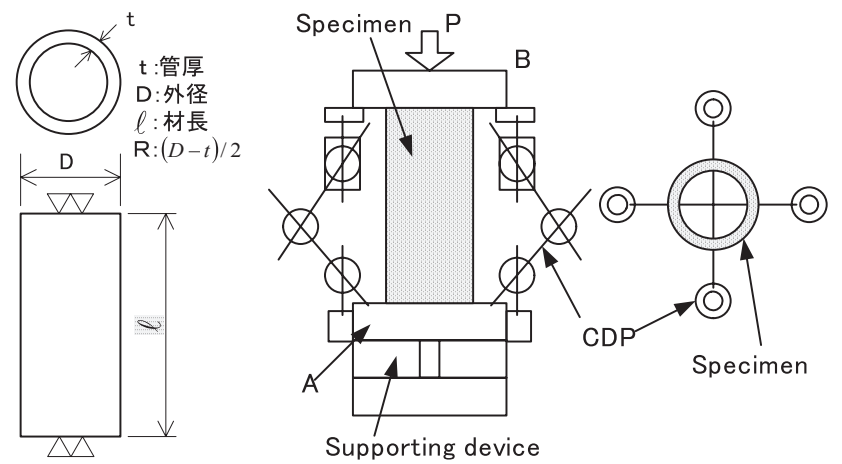

図 1 試験体形状

図 2 加力と測定方法

\section{2 実験方法}

実験は図 2 に示すような中心圧縮による平押しである。試験体は 台座の上に載せてあるのみである。用いた試験機は 200ton スクリ ユータイプ万能試験機であり、実験の詳細は文献(7)を参照されたい。

\section{3 材料の機械的性質}

材料の機械的性質を調べるために引張素材試験を行った。引張試 験片は試験体と一緒に焼鈍炉にいれ試験体の熱環境と同じとした。 引張試験による機械的性質を表 4 に示す。同表中の記号の定義は以 下の通りである。

$\begin{array}{ll}\sigma_{y} & : \text { 降伏応力度 } \\ \sigma_{\max } & : \text { 最大応力度 } \\ Y R & : \text { 降伏比 } \\ \varepsilon_{y} & : \text { 降伏歪 } \\ \varepsilon_{\max } & : \text { 伸び } \\ E & : \text { ヤング係数 } \\ \varepsilon_{S t} & : \text { 歪硬化開始点の歪 } \\ E_{S t} & : \text { 歪硬化域での初期接線勾配 }\left(\mathrm{N} / \mathrm{mm}^{2}\right) \\ \beta_{t} & : \text { 歪硬化開始点歪の無次元值 }\left(\varepsilon_{s t} / \varepsilon_{y}\right) \\ h_{t} \mathrm{~h}_{t} & : \mathrm{E} / \mathrm{E}_{\mathrm{st}}\end{array}$

表 1 試験体寸法（SS400）

\begin{tabular}{|c|c|c|c|c|c|}
\hline $\begin{array}{c}\text { 試験 } \\
\text { 体名 }\end{array}$ & $\begin{array}{c}\mathrm{t} \\
(\mathrm{mm})\end{array}$ & $\begin{array}{c}\mathrm{D} \\
(\mathrm{mm})\end{array}$ & $\begin{array}{c}\ell \\
(\mathrm{mm})\end{array}$ & $\mathrm{R} / \mathrm{t}$ & $\tau$ \\
\hline $\mathrm{CL} 3$ & 6.0 & 60 & 150 & 4.50 & 2.29 \\
\hline CL4 & 4.0 & 60 & 150 & 7.02 & 1.94 \\
\hline CL5 & 3.00 & 60 & 150 & 9.50 & 1.73 \\
\hline CL6 & 2.4 & 60. & 150 & 11.9 & 1.59 \\
\hline CL7 & 2.0 & 60. & 150 & 14.6 & 1.47 \\
\hline CL8 & 1.7 & 60 & 150 & 17.2 & 1.36 \\
\hline CL9 & 1.5 & 60 & 150 & 19.4 & 1.28 \\
\hline CL10 & 1.3 & 60 & 150 & 22.0 & 1.28 \\
\hline \hline CS8 & 1.7 & 60 & 100 & 17.0 & 1.38 \\
\hline CS9 & 1.5 & 60 & 100 & 19.3 & 1.27 \\
\hline CS10 & 1.3 & 60 & 100 & 21.9 & 1.32 \\
\hline CS11 & 1.2 & 60 & 100 & 23.9 & 1.23 \\
\hline CS12 & 1.1 & 60 & 100 & 26.5 & 1.18 \\
\hline CS13 & 1.0 & 60 & 100 & 28.9 & 1.15 \\
\hline CS14 & 0.94 & 60 & 100 & 31.4 & 1.07 \\
\hline CS15 & 0.87 & 60 & 100 & 33.9 & 1.10 \\
\hline CS16 & 0.79 & 60 & 100 & 37.4 & 1.06 \\
\hline CS17 & 0.74 & 60 & 100 & 40.0 & 1.02 \\
\hline CS18 & 0.70 & 60 & 100 & 42.3 & 1.01 \\
\hline
\end{tabular}

表 2 試験体寸法（STPT410-S-H）

\begin{tabular}{|c|c|c|c|c|c|}
\hline $\begin{array}{c}\text { 試験 } \\
\text { 体名 }\end{array}$ & $\begin{array}{c}\mathrm{T} \\
(\mathrm{mm})\end{array}$ & $\begin{array}{c}\mathrm{D} \\
(\mathrm{mm})\end{array}$ & $\begin{array}{c}\ell \\
(\mathrm{mm})\end{array}$ & $\mathrm{R} / \mathrm{t}$ & $\tau$ \\
\hline $\mathrm{st}-1$ & 5.9 & 60 & 148 & 4.50 & 1.93 \\
\hline $\mathrm{st}-2$ & 4.9 & 60 & 148 & 5.52 & 1.82 \\
\hline $\mathrm{st}-3$ & 3.9 & 60 & 148 & 7.03 & 1.64 \\
\hline $\mathrm{st}-4$ & 2.9 & 60 & 148 & 9.53 & 1.50 \\
\hline $\mathrm{st}-5$ & 2.4 & 60 & 148 & 11.9 & 1.39 \\
\hline $\mathrm{st}-6$ & 2.0 & 60 & 148 & 14.6 & 1.33 \\
\hline $\mathrm{st}-7$ & 1.7 & 60 & 148 & 16.5 & 1.26 \\
\hline $\mathrm{st}-8$ & 1.5 & 60 & 148 & 19.4 & 1.16 \\
\hline $\mathrm{st}-9$ & 1.3 & 60 & 148 & 21.8 & 1.14 \\
\hline $\mathrm{st}-10$ & 1.2 & 60 & 148 & 24.7 & 1.06 \\
\hline $\mathrm{st}-11$ & 1.1 & 60 & 148 & 27.3 & 1.00 \\
\hline $\mathrm{st}-12$ & 1.0 & 60 & 148 & 29.3 & 0.97 \\
\hline $\mathrm{st}-13$ & 0.8 & 60 & 148 & 34.6 & 1.00 \\
\hline $\mathrm{st}-14$ & 0.84 & 60 & 148 & 37.3 & 1.00 \\
\hline $\mathrm{st}-15$ & 0.66 & 60 & 148 & 44.2 & 0.97 \\
\hline $\mathrm{st}-16$ & 0.61 & 60 & 148 & 48.6 & 0.99 \\
\hline $\mathrm{st}-17$ & 0.54 & 60 & 148 & 54.1 & 1.00 \\
\hline $\mathrm{st}-18$ & 0.50 & 60 & 148 & 58.4 & 0.97 \\
\hline
\end{tabular}




\begin{tabular}{|c|c|c|c|c|c|}
\hline $\begin{array}{c}\text { 試験 } \\
\text { 体名 }\end{array}$ & $\begin{array}{c}\mathrm{t} \\
(\mathrm{mm})\end{array}$ & $\begin{array}{c}\mathrm{D} \\
(\mathrm{mm})\end{array}$ & $\begin{array}{c}\ell \\
(\mathrm{mm})\end{array}$ & $\mathrm{R} / \mathrm{t}$ & $\tau$ \\
\hline $\mathrm{sc}-1$ & 6.6 & 60 & 148 & 4.00 & 2.13 \\
\hline $\mathrm{sc}-2$ & 5.9 & 60 & 148 & 4.50 & 2.05 \\
\hline $\mathrm{sc}-3$ & 4.9 & 60 & 148 & 5.50 & 1.95 \\
\hline $\mathrm{sc}-4$ & 3.9 & 60 & 148 & 7.04 & 1.82 \\
\hline $\mathrm{sc}-5$ & 3.0 & 60 & 148 & 9.50 & 1.70 \\
\hline $\mathrm{sc}-6$ & 2.4 & 60 & 148 & 12.0 & 1.58 \\
\hline $\mathrm{sc}-7$ & 2.0 & 60 & 147 & 14.6 & 1.50 \\
\hline $\mathrm{sc}-8$ & 1.7 & 60 & 148 & 17.0 & 1.41 \\
\hline $\mathrm{sc}-9$ & 1.5 & 60 & 147 & 19.3 & 1.33 \\
\hline $\mathrm{sc}-10$ & 1.3 & 60 & 148 & 22.2 & 1.30 \\
\hline $\mathrm{sc}-11$ & 1.2 & 60 & 148 & 24.9 & 1.23 \\
\hline $\mathrm{sc}-12$ & 1.1 & 60 & 147 & 27.1 & 1.18 \\
\hline $\mathrm{sc}-13$ & 0.98 & 60 & 148 & 29.6 & 1.15 \\
\hline $\mathrm{sc}-14$ & 0.83 & 60 & 147 & 35.0 & 1.07 \\
\hline $\mathrm{sc}-15$ & 0.72 & 60 & 148 & 40.8 & 0.99 \\
\hline $\mathrm{sc}-16$ & 0.65 & 60 & 148 & 45.0 & 1.00 \\
\hline $\mathrm{sc}-17$ & 0.58 & 60 & 148 & 50.4 & 0.98 \\
\hline $\mathrm{sc}-18$ & 0.54 & 60 & 147 & 54.0 & 1.00 \\
\hline $\mathrm{sc}-19$ & 0.48 & 60 & 147 & 61.0 & 1.0 \\
\hline
\end{tabular}

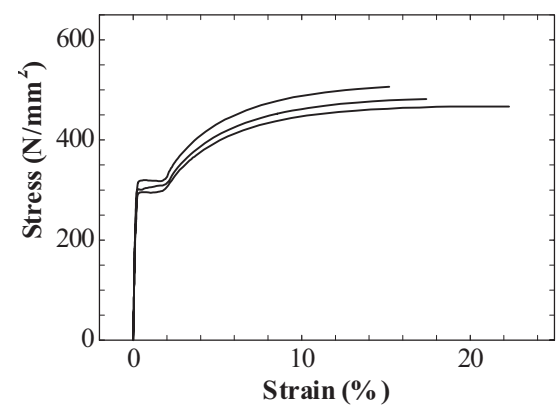

図 3 引張試験結果（STPT410-S-H）

表 4 材料の機械的性質

\begin{tabular}{|c|c|c|c|}
\hline Material & SS400 & STPT410-S-H & STKM-S45C \\
\hline$\sigma_{y}\left(\mathrm{~N} / \mathrm{mm}^{2}\right)$ & 258 & 304 & 398 \\
\hline$\sigma_{\max }\left(\mathrm{N} / \mathrm{mm}^{2}\right)$ & 456 & 485 & 715 \\
\hline $\left.\mathrm{YR}^{2} \%\right)$ & 57 & 63 & 56 \\
\hline$\varepsilon_{\mathrm{y}}(\%)$ & 0.125 & 0.148 & 0.194 \\
\hline$\varepsilon_{\max }(\%)$ & 15.9 & 17.13 & 13.8 \\
\hline $\mathrm{E}\left(\mathrm{N} / \mathrm{mm}^{2}\right)$ & 205,000 & 205,000 & 205,000 \\
\hline$\varepsilon_{\mathrm{st}}(\%)$ & 0.771 & 1.86 & 0.773 \\
\hline $\mathrm{E}_{\mathrm{st}}\left(\mathrm{N} / \mathrm{mm}^{2}\right)$ & 4724 & 5481.3 & 10099 \\
\hline$\beta_{\mathrm{t}}$ & 6.17 & 12.6 & 3.98 \\
\hline $\mathrm{h}_{\mathrm{t}}$ & 43.4 & 37.4 & 20.3 \\
\hline
\end{tabular}

\begin{tabular}{|c|c|c|c|}
\hline Material & SS400 & STPT410-S-H & STKM-S45C \\
\hline${ }_{\mathrm{c}} \sigma_{\mathrm{y}}\left(\mathrm{N} / \mathrm{mm}^{2}\right)$ & 262 & 295 & 396 \\
\hline $\mathrm{c} \varepsilon_{\mathrm{y}}(\%)$ & 0.13 & 0.144 & 0.193 \\
\hline $\mathrm{c} \varepsilon_{\mathrm{st}}(\%)$ & 0.436 & 1.09 & 0.675 \\
\hline${ }_{\mathrm{c}} \mathrm{E}_{\mathrm{st}}$ & 4,964 & 5,742 & 10,250 \\
\hline$\beta$ & 3.35 & 7.60 & 3.50 \\
\hline $\mathrm{h}$ & 41.3 & 35.7 & 20.0 \\
\hline
\end{tabular}

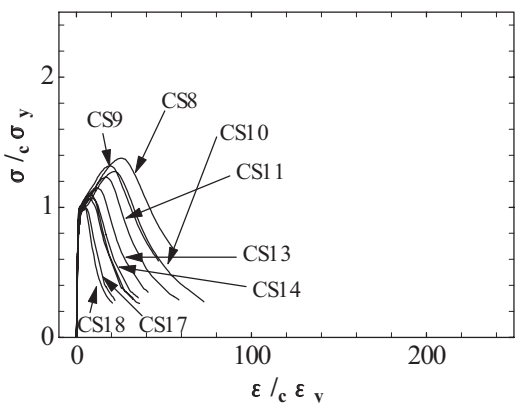

図 4-(a) $\sigma /{ }_{c} \sigma_{y}-\varepsilon / c_{c} \varepsilon_{y}$ 関係（SS400 CS シリーズ）

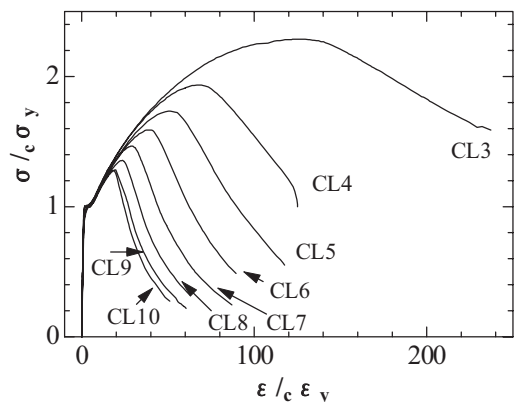

図 4-(b) $\quad \sigma / c \sigma_{y}-\varepsilon / c \varepsilon_{y}$ 関係（SS400 CL シリーズ）

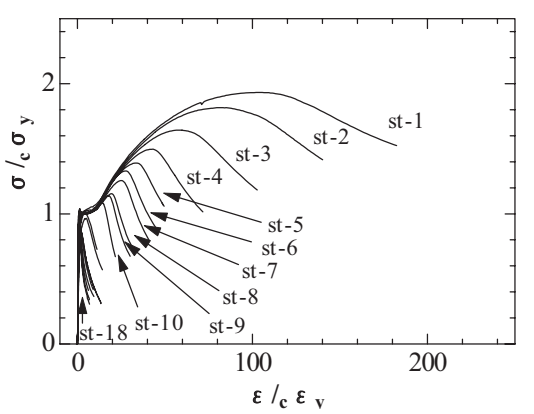

図 $5 \sigma /{ }_{c} \sigma_{y}-\varepsilon / c \varepsilon_{y}$ 関係(STPT410-S-H)

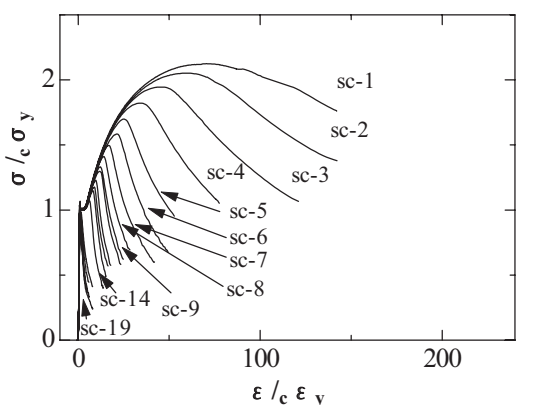

図 $6 \sigma /{ }_{c} \sigma_{y}-\varepsilon / c \varepsilon_{y}$ 関係(STKM-S45C) 
実験によって得られた圧縮性状を表 5 に示す。同表中の記号の定 義は圧縮を示寸添え字 $\mathrm{c}$ を付け加えた以外は引張性状における場合 と同じ意味である。引張試験結果を、扱った材質の中から代表して 材質 STPT410-S-H のみについて図 3 に示す。

\section{4 円形鋼管短柱の圧縮実験結果}

降伏歪 ${ }_{c} \varepsilon_{y}$ で除して無次元化した $\sigma /{ }_{c} \sigma_{y}-\varepsilon / c_{c} \varepsilon_{y}$ 関係を得た。そ のグラフを図 4 (a)(b), 5, 6 に示す。図 4 は CS と CL の二つのシリ ーズに分かれている。

\section{4. 理論座屈式と実験結果との比較}

\subsection{Richard の式による実験結果の近似}

歪硬化域における $\sigma /{ }_{c} \sigma_{y}-\varepsilon /{ }_{c} \varepsilon_{y}$ 関係の最も外側を通る曲線は 径厚比の最も小さな試験体のカーブで代表される包絡線となるこの 包絡線はそれぞれの材質によって異なり、Richard の式 8) の基本形 (4.1)式を基に近似させる。ここで圧縮実験から得られたそれぞれの 材質の近似式の中から代表して材質 STPT410-S-H のみについて

（4.2）式に示し、図 7 で近似式を実験から得た曲線と比べた。

Richard の式の基本形

$$
\frac{\sigma}{c^{\sigma} y}=1.0+\frac{\left(\frac{\varepsilon}{c^{\varepsilon} y}-\frac{\varepsilon_{s t}}{c^{\varepsilon} y}\right) / \frac{E}{E_{s t}}}{\left[1.0+\left|\frac{\left(\frac{\varepsilon}{c^{\varepsilon} y}-\frac{\varepsilon_{s t}}{c^{\varepsilon} y}\right) / \frac{E}{E_{s t}}}{\left(\frac{\sigma \max }{c^{\sigma} y}-1.0\right)}\right|^{n}\right]^{\frac{1}{n}}}
$$

Richard の式（st-1 に近似 STPT410-S-H）

$$
\begin{aligned}
& \frac{\sigma}{c^{\sigma} y}=1.0+\frac{\left(\frac{\varepsilon}{c^{\varepsilon} y}-7.6\right) / 35.7}{\left[1.0+\left|\frac{\left(\frac{\varepsilon}{c^{\varepsilon} y}-7.6\right) / 35.7}{(2.2-1.0)}\right|^{1.4}\right]^{\frac{1}{1.4}}} \\
& \left(\begin{array}{l}
\sigma / c^{\sigma}{ }_{\mathrm{y}} \geq 1 \\
\varepsilon / \mathrm{c} \varepsilon_{\mathrm{y}} \geq 7.6
\end{array}\right)
\end{aligned}
$$

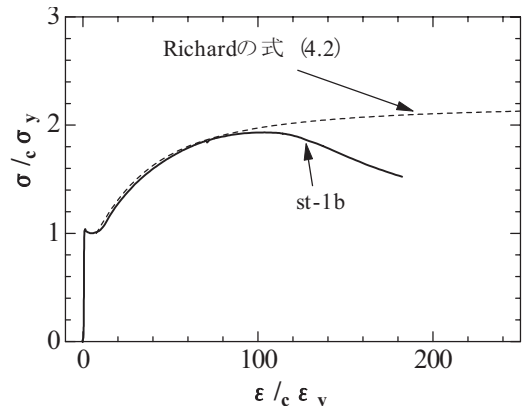

図 7 近似曲線（STPT410-S-H）

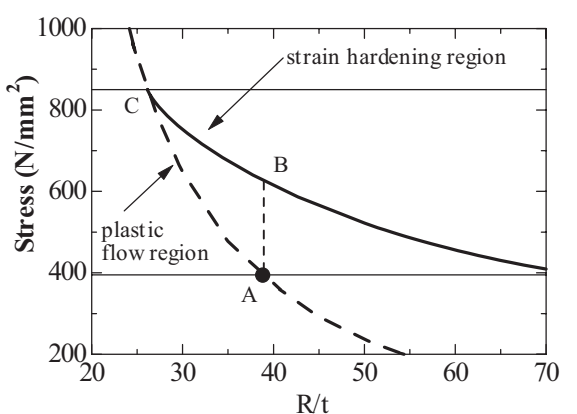

図 8 歪増分理論による 座屈曲線（STKM-S45C）

（座屈半波長を $8 \mathrm{~mm}$ と仮定）

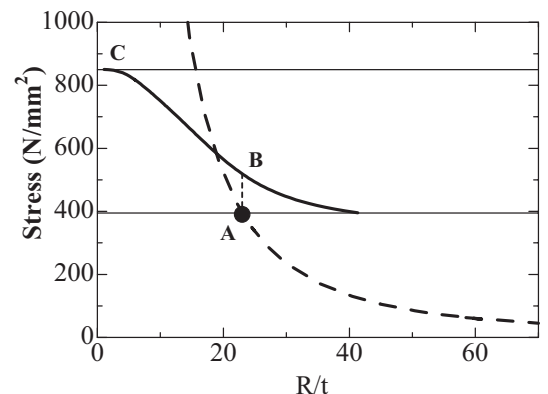

図 9 変形理論による座屈曲線(STKM-S45C) (座屈半波長を $8 \mathrm{~mm}$ と仮定)

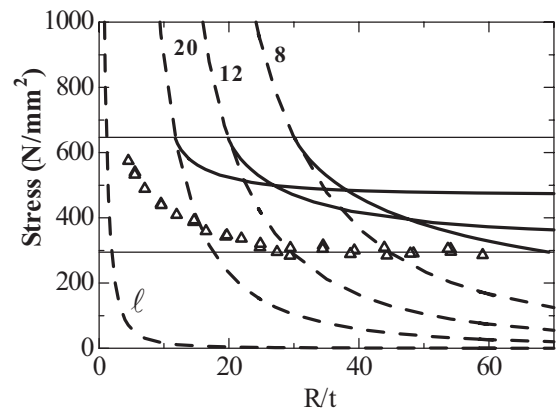

図１０歪増分理論による座屈曲線（STPT-410-S-H）

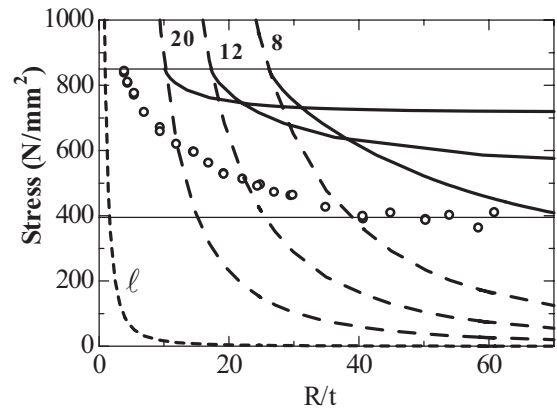

図 11 歪増分理論による座屈曲線（STKM-S45C） 


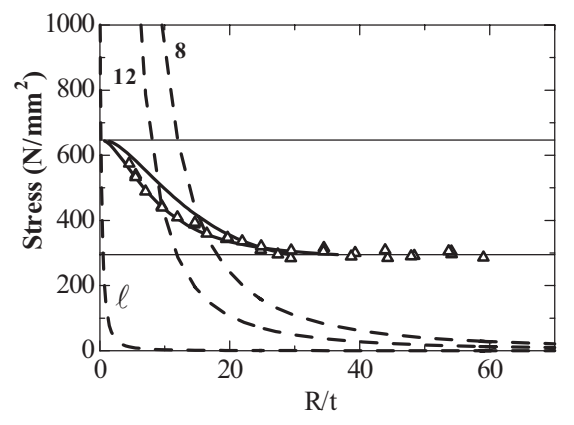

図 12 変形理論による座屈曲線（STPT-410-S-H）

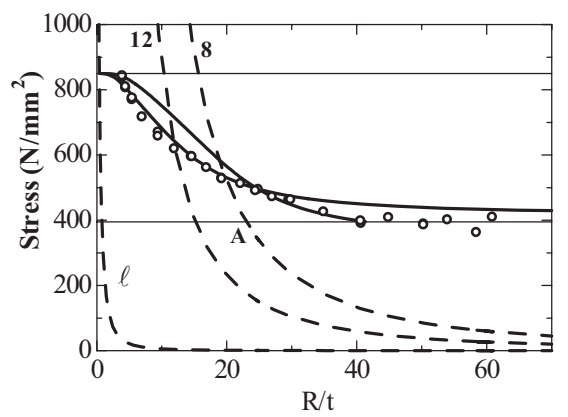

図 13 変形理論による座屈曲線（STKM-S45C)

\section{2 理論座屈式}

\subsection{1 境界条件}

前記の椂に試験体は台座の上に載せてあるのみである。従って端 部境界条件としては、半径方向の変位と回転が自然に拘束されてい る可能性がある。これによる縁摚乱たわみは荷重が座屈荷重に達し たときでもポアソン比による平均半径方向膨張を中心に、高々それ と同量の振幅しか発生しない。この量は小さく実験結果を材端ピン 支持の座屈荷重と等しいとみた。

\section{2 .2 塑性流れ域での安定性}

(歪増分理論)

STKM-S45C の座屈半波長を $8 \mathrm{~mm}$ と仮定した場合の、塑性流れ域 の座屈式(2.9)を用いて画いた曲線が図 8 中の破線である。同図中に は歪硬化域でも座屈半波長が同じ $8 \mathrm{~mm}$ であると仮定して画いた座 屈曲線が実線で画いてある。同図中下の水平線は降伏応力度、上の 水平線は最大応力度である。塑性流れ域においては、応力度は降伏 応力度であるので、破線の座屈曲線は $\mathrm{A}$ 点ただ一点のみ意味がある。 $\mathrm{A}$ 点より大きい径厚比のものは、降伏応力度を超えられず、小さい 径厚比のものは、降伏応力度を超え歪硬化域に達してから座屈する。 この境界となる径厚比のところで応力は $\mathrm{A}$ 点から $\mathrm{B}$ 点にジャンプし、 これ以下の径厚比ではで $\mathrm{B}$ 点以上の座屈曲線が当てはまる。 $\mathrm{C}$ 点は 最大応力度であるのでこれを超えることはない。破線と実線は最大 応力度のところで交わる。その理由は、実線は最大応力度のところ では $E_{t}=0$ であり、ここでは塑性流れ域と同じ特性となるからであ る。図 8 中 $\mathrm{C}$ 点より左の領域では座屈がおこらないことになる。

座屈半波長を一定值に仮定して、材質 STPT-410-S-H と STKM-S45C に対して座屈曲線を画いたものが図 10、および図 11 である。座屈半波長は図中に示される $8,12,20 \mathrm{~mm}$ と材長 $\ell$ の四種
類とした。同図中破線は $E_{t}=0(2.9)$ 式、実線は歪硬化域(2.1)式中の パラメータに $\psi=1$ を適用した歪増分理論解である。プロットは実 験結果である。

\section{(変形理論)}

STKM-S45C の座屈半波長を $8 \mathrm{~mm}$ と仮定した場合の、塑性流れ 域の座屈式(2.8)を用いて画いた曲線が図 9 中の破線である。同図中 には歪硬化域でも座屈半波長が同じ $8 \mathrm{~mm}$ であると仮定して画いた 座屈曲線が実線で画いてある。図 8 と同様に $\mathrm{A}$ 点を境に、降伏応力 度を超えることができない領域と超えることができる領域に分かれ る。図 8 とは $\mathrm{C}$ 点の位置が異なり、 $\mathrm{C}$ 点は横軸 0 の位置でその大き さは最大応力度である。

座屈半波長を一定值に仮定して、材質 STPT-410-S-H と STK-S45C に対して座屈曲線を画いたものが図 12、および図 13 で ある。座屈半波長は図中に示される $8,12 \mathrm{~mm}$ と,材長 $\ell$ の 3 種類 と した。同図中破線は $E_{t}=0(2.8)$ 式、実線は歪硬化域(2.5)式である。

\section{2 .3 歪硬化域における最小座屈値}

理論座屈曲線として歪硬化域における変形理論および歪増分理論 による座屈式を実験結果との比較に用いる。いずれも塑性化が充分 進行した後に局部座屈する場合の最小解である。変形理論について は材端が単純支持、歪増分理論については材端が単純支持と自由境 界の二つの場合の解を取り上げた。理論座屈式は(2.5),(2.7),(2.9)式 から座屈応力度を降伏応力度で除して無次元化した応力上昇率 $\tau$ の形で表す。式中の接線係数と割線係数の值は Richard の式から求 めた。

（1）変形理論

$$
\tau=\frac{\sigma_{c r}}{c^{\sigma_{y}}}=\frac{2}{3} \sqrt{\frac{E_{t}}{E} \frac{E_{S}}{E}} \frac{1}{(R / t)_{c} \varepsilon_{y}}
$$

（2）歪増分理論

$$
\tau=\frac{\sigma_{c r}}{{ }_{c} \sigma_{y}}=\frac{1}{1.69} \sqrt{\frac{E_{t}}{E}} \frac{1}{(R / t)_{c^{\varepsilon} y}}
$$

（3）自由境界に対する歪増分理論

$$
\tau=\frac{\sigma_{c r}}{{ }^{\sigma_{y}} y}=\frac{1}{3.38} \sqrt{\frac{E_{t}}{E}} \frac{1}{(R / t)_{c^{\varepsilon} y}}
$$

\section{2 .4 実験結果と最小理論座屈式との比較}

歪硬化域における最小理論座屈式(4.3),(4.4)(4.5)に基づいて $\tau-(R / t)_{c} \varepsilon y$ 曲線を画いたのが、図 $14,15,16$ である。 $\tau$ の実験結 果は表 1〜表 3 に示される。これらの図より歪増分理論は実験值に 対してかなり大きい值を与えている。自由境界に対する歪増分理論 では実験值にはかなり近づくが、それでもまだ大きい解を与えてい る。それに対して変形理論は実験值に非常に近い解を与えている。

上記座屈曲線のうち材質 STKM-S $45 \mathrm{C}$ に対する図 16 を変形理 論に対して画かれた図 9 と比較すると両図中の座屈曲線に若干の食 い違いがある。座屈曲線は本来図 9 のように示され、塑性流れ域の 座屈曲線が降伏応力度レベルをよぎる点の径厚比（およそ 22 ）の短 柱は、応力度が降伏応力度から歪硬化域の座屈曲線（B 点）に向け 
てジャンプする。ところが図 14１6 はジャンプがなく滑らかで、 図 9 と比べて径厚比の大きい領域で降伏応力度を超えている。この 理由は図 13 を例に説明する。同図で座屈半波長が $8 \mathrm{~mm}$ なら $\mathrm{A}$ 点 が一つの境界になりそこでジャンプし、歪硬化域の座屈曲線に移行 する。座屈半波長が $8 \mathrm{~mm}$ 固定なら $\mathrm{A}$ 点より径厚比が大きい領域で は理論と実験結果が合わないと言えるが、径厚比が大きくなるに連 れて、次第に座屈半波長が短くなることを考えると、ジャンプする 位置が A点より右にずれ、ジャンプする大きさも次第に小さくなり、 結果として滑らかな曲線となると思われる。

\section{3 座屈半波長の理論值と実験結果}

歪硬化域における理論座屈式は、(2.2)式による座屈半波長がその 最小值を与える。その半波長をSTKM-S45C について、実験後に試 験体から測定した長さと比較したのが図 17 である。

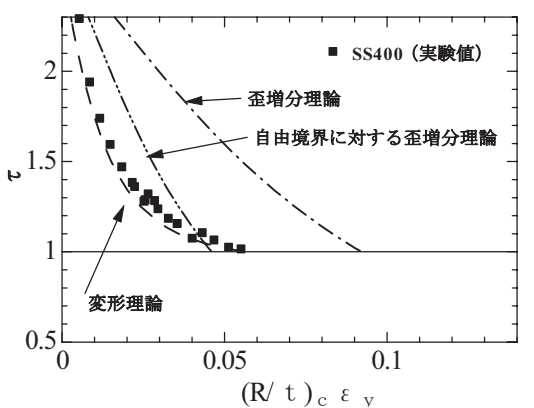

図 $14 \tau-(R / t)_{c} \varepsilon_{y}$ 曲線(SS400)

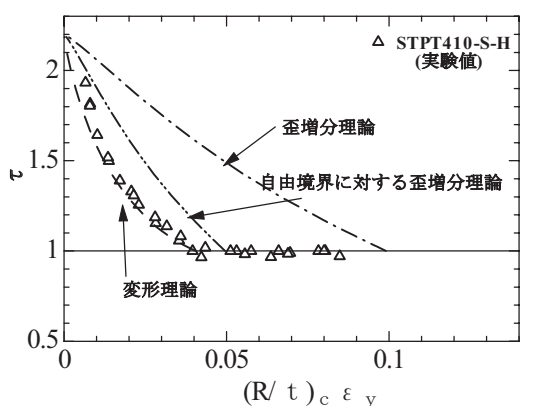

図 $15 \tau-(R / t)_{c} \varepsilon_{y} \quad$ 曲線(STPT410-S-H)

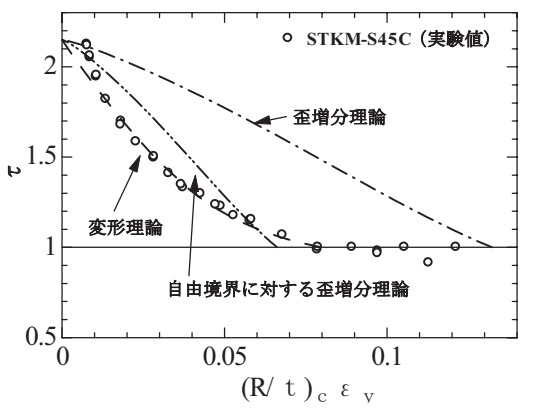

図 $16 \tau-(R / t)_{c} \varepsilon_{y}$ 曲線 (STKM-S45C)

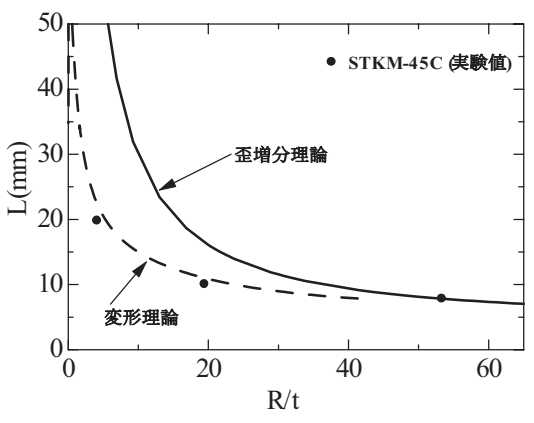

図 17 座屈半波長 L と径厚比 R/t との関係（STKM-S-45C）

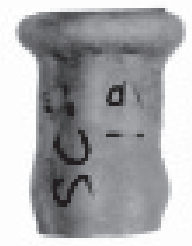

写真 $1 \quad \mathrm{SC}-1$ の実験後 $\mathrm{R} / \mathrm{t}=4$

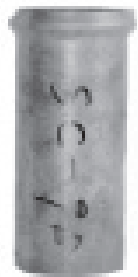

写真 2 SC-9 の実験後 R/t=19.3

$\mathrm{R} / \mathrm{t}=4$ でおよそ $20 \mathrm{~mm} 、 \mathrm{R} / \mathrm{t}=19$ でおよそ $10 \mathrm{~mm} 、 \mathrm{R} / \mathrm{t}=54$ でおよそ $8 \mathrm{~mm}$ であった。同図によれば、実験による座屈半波長は理論值、 特に変形理論のカーブにのっているという結果を得た

5. 結論

1）圧縮を受ける円形鋼管の塑性流れ域における安定性を理論的 に検討した。その結果、よく知られている座屈式には、歪増分 理論によっても、変形理論によっても、座屈式に $E_{t}$ の項がか かっていて発散する項を含んでいるが、 $E_{t} \rightarrow 0$ の極限が存在 する。塑性流れ域ではこの極限をとった式を適用すればよいこ とが分かった。

2) 1)で得た $E_{t} \rightarrow 0$ の極限をとった式は、長さに反比例する形な ので座屈半波長を無限大としたときに、耐力 0 を与え、塑性流 れ域で不安定となることを示している。しかし長さは短柱の長 さとして有限で、又実験で観察される座屈波形のモードは象の 足モードで、端部近傍の短い波長である。この半波長を座屈式 に適用すれば、径厚比によっては塑性流れ域での座屈を経ずし て歪硬化域に達し得る事が説明できる。

3）塑性流れ域の長さ、そして降伏比の異なる鋼材質を選んで、径 厚比を変化させた 3 種類のシリーズの短柱圧縮実験を行い、座 
屈理論解と比較した。

4）座屈半波長は材質 STKM-S-45C の試験体で測った。径厚比の 大きいところでは座屈半波長の理論值は、歪増分理論と変形理 論とが近接するので、実験值は両方の理論值に近い。径厚比が 小さいところでは、実験值は変形理論に近く、歪増分理論の予 測値は実験值よりかなり大きい。

5）歪硬化域での座屈耐力式は、歪増分理論は実験結果よりはるか に高く、自由境界に対する歪増分理論はかなり実験值に近づく が、それでもまだ大きい解を与えている。変形理論は塑性流れ を有する場合でも 3 種類すべての実験結果とよく合うという 結果を得た。

\section{謝辞}

この研究の実験で用いた試験体の製作費は日本学術振興会から交 付された科学研究費補助金 (基盤研究C) および住友金属工業（株） からの奨学寄附金によるものです。梁く感謝いたします。

\section{6. 参考文献}

1) Donnel, L. H., :Stability of thin-walled tubes under torsion, N. A. C. A Report, No. 479, 1933

2) Batterman, S. C., :Plastic Buckling of Axially Compressed Cylindrical Shells, AIAA J. , Feb. , 1965

3) Gerald, G. , :Compressive and torsional buckling of thin-wall cylinders in yielded region, N. A.C.A,T.N. 3726 Aug. 1956

4) ) Batterman, S. C. and Lee, L. H. , :Effect of modes of plastic buckling of compressed cylindrical shells, AIAA J. Dec. 1966

5) 加藤勉、秋山宏、鈴木弘之 : 軸圧縮力を受ける鋼管の塑性局部座屈耐力、 日本建築学会論文報告集、第 204 号、1973 年

6) Batterman, S. C. :Free-Edge Plastic Buckl-ing of Axially Compressed Cylindrical Shells, J. of Appl. Mech. , March, 1968

7)井上哲郎、中村陽一：圧縮を受ける円形鋼管短柱の塑性座屈

一平板との対比一,鋼構造論文集第 10 巻第 39 号 2003 年

8) Richard, R. D. and Goldberg, J. E. :Analysis of Nonlinear Structures, Force Method, J. of Structural Division, ASCE, Vo1.91, No. ST6, Proc. Paper, 1965

\section{(APPENDIX I )}

\section{塑性流れ域での応力増分と歪増分との関係} （塑性流れ域）

歪増分理論の非硬化材料に対する Reuss の方程式から

平面応力状態 $\left(\sigma_{z}=\tau_{z x}=\tau_{y z}=0\right)$ において

$$
\left.\begin{array}{l}
\dot{\varepsilon}_{x}=\frac{1}{E}\left(\dot{\sigma}_{x}-v \dot{\sigma}_{y}\right)+\frac{1}{3}\left(2 \sigma_{x}-\sigma_{y}\right) d \lambda \\
\dot{\varepsilon}_{y}=\frac{1}{E}\left(\dot{\sigma}_{y}-v \dot{\sigma}_{x}\right)+\frac{1}{3}\left(2 \sigma_{y}-\sigma_{x}\right) d \lambda
\end{array}\right\}
$$

偏差応力の 2 次不変量は

$$
J_{2}^{\prime}=\frac{1}{3}\left(\sigma_{x}^{2}-\sigma_{x} \sigma_{y}+\sigma_{y}{ }^{2}\right)
$$

となる。 $\dot{J}_{2}^{\prime}=0$ より

$$
\dot{J}_{2}^{\prime}=\frac{1}{3}\left(2 \sigma_{x}-\sigma_{y}\right) \dot{\sigma}_{x}+\frac{1}{3}\left(2 \sigma_{y}-\sigma_{x}\right) \dot{\sigma}_{y}=0
$$

一軸圧縮の場合 $\left(\sigma_{y}=\sigma_{z}=\tau_{y z}=\tau_{z x}=\tau_{x y}=0\right)$

$$
\dot{J}_{2}^{\prime}=\frac{2}{3} \sigma_{x} \dot{\sigma}_{x}-\frac{1}{3} \sigma_{x} \dot{\sigma}_{y}=0
$$

よって

$$
\dot{\sigma}_{y}=2 \dot{\sigma}_{x}
$$

(A-4)を(A-1)に代入すると

$$
\left.\begin{array}{c}
\dot{\varepsilon}_{x}=\frac{1}{E}(1-2 v) \dot{\sigma}_{x}+\frac{2}{3} \sigma_{x} d \lambda \\
\dot{\varepsilon}_{y}=\frac{1}{E}(2-v) \dot{\sigma}_{x}-\frac{1}{3} \sigma_{x} d \lambda
\end{array}\right\}
$$

$(\mathrm{A}-5)$ より

$$
d \lambda=\frac{3}{2 \sigma_{x}}\left\{\dot{\varepsilon}_{x}-\frac{1}{E}(1-2 v) \dot{\sigma}_{x}\right\}=\frac{3}{\sigma_{x}}\left\{-\dot{\varepsilon}_{y}+\frac{1}{E}(2-v) \dot{\sigma}_{x}\right\}
$$

$(\mathrm{A}-5)$ より

$$
\left.\begin{array}{c}
\dot{\sigma}_{x}=\frac{E}{5-4 v}\left(\dot{\varepsilon}_{x}+2 \dot{\varepsilon}_{y}\right) \\
\dot{\sigma}_{y}=\frac{2 E}{5-4 v}\left(\dot{\varepsilon}_{x}+2 \dot{\varepsilon}_{y}\right)
\end{array}\right\}
$$

を得る。

\section{(歪硬化域)}

歪硬化域では下式が成り立つことが知られている。この式は変形 理論による表示で、パラメータを適切に選べば、弾性域をも、歪硬 化域をも表わす一般形である。

$$
\begin{aligned}
& \dot{\sigma}_{x}=a_{11} \dot{\varepsilon}_{x}+a_{12} \dot{\varepsilon}_{y} \\
& \dot{\sigma}_{y}=a_{12} \dot{\varepsilon}_{x}+a_{22} \dot{\varepsilon}_{y} \\
& \dot{\tau}_{x y}=a_{3} \dot{\gamma}_{x y} \\
& a_{11}=B \frac{\lambda+3 \psi}{4}, \quad a_{12}=B \frac{\lambda+2 v-1}{2} \\
& a_{22}=B \lambda, \quad a_{3}=\frac{E}{3 \psi+2 v-1} \\
& B E=a_{11} a_{22}-a_{12}{ }^{2}=\frac{4 E^{2}}{(3 \psi+2-4 v) \lambda-(1-2 v)^{2}} \\
& \lambda=E / E_{t} \\
& \psi=E / E_{S}
\end{aligned}
$$

$\psi=1,\left(E_{S}=E\right)$ とすれば歪増分理論になり

$\lambda=\psi=1, \quad\left(E_{t}=E_{S}=E\right)$ とすれば Hook の法則になる。

歪増分理論の $(\mathrm{A}-8)$ 式で $\psi=1$ とし、 $E_{t} \rightarrow 0$ の極限をとると、

$$
a_{11}=\frac{E}{5-4 v}, \quad a_{12}=\frac{2 E}{5-4 v}, \quad a_{22}=\frac{4 E}{5-4 v},
$$

これは塑性流れ域の(A-7)式と一致する。したがって、理論座屈式 は歪硬化域の解で $E_{t} \rightarrow 0$ の極限をとれば、塑性流れ域の解を表わし ていると考える。変形理論の場合も同様の扱いと考える。 